\title{
Vitamin $\mathrm{K3}$ induces antiproliferative effect in cervical epithelial cells transformed by HPV 16 ( $\mathrm{SiHa}$ cells) through the increase in reactive oxygen species production
}

\author{
Natália de Carvalho Scharf Santana ${ }^{1} \cdot$ Natália Alves Lima $^{1} \cdot$ Vânia Cristina Desoti $^{3}$. \\ Danielle Lazarin Bidóia ${ }^{3}$ - Patrícia de Souza Bonfim Mendonça ${ }^{2}$ - Bianca Altrão Ratti ${ }^{1}$. \\ Tânia Ueda Nakamura ${ }^{4}$. Celso Vataru Nakamura ${ }^{4}$. Marcia Edilaine Lopes Consolaro ${ }^{5}$. \\ Valdecir Farias Ximenes ${ }^{6} \cdot$ Sueli de Oliveira Silva ${ }^{4}$
}

Received: 25 November 2015 / Accepted: 5 April 2016/Published online: 18 April 2016

(C) Springer-Verlag Berlin Heidelberg 2016

\begin{abstract}
Purpose Cervical cancer is characterized as an important public health problem. According to latest estimates, cancer of the cervix is the fourth most common cancer among women. Due to its high prevalence, the search for new and efficient drugs to treat this infection is continuous. The progression of HPV-associated cervical cancer involves the expression of two viral proteins, E6 and E7, which are rapidly degraded by the ubiquitin-proteasome system through the increase in reactive oxygen species generation. Vitamins are essential to human substances, participate in the regulation of metabolism, and facilitate the process of energy transfer.
\end{abstract}

Sueli de Oliveira Silva

lautenschlager@uem.br

1 Programa de Pós-graduação em Biociências Aplicadas á Farmácia, Universidade Estadual de Maringá, Av. Colombo, 5.790, 87020-900 Maringá, PR, Brazil

2 Programa de Pós-graduação em Ciências da Saúde, Universidade Estadual de Maringá, Av Colombo, 5.790, Maringá, PR 87020-900, Brazil

3 Programa de Pós-graduação em Ciências Farmacêuticas, Universidade Estadual de Maringá, Av Colombo, 5.790, Maringá, PR 87020-900, Brazil

4 Departamento de Ciências Básicas da Saúde, Universidade Estadual de Maringá, Av. Colombo, 5.790, Bloco I-90, Maringá, PR 87020-900, Brazil

5 Departamento de Análises Clínicas e Biomedicina, Universidade Estadual de Maringá, Av. Colombo, 5.790, Maringá, PR 87020-900, Brazil

6 Departamento de Química, Faculdade de Ciências, Universidade Estadual Paulista Júlio de Mesquita Filho, Av Eng Luiz Edmundo Carrijo Coube, S/N, Bauru, SP 17033360, Brazil
Methods Some early studies have indicated that vitamin K3 exerts antitumor activity by inducing cell death by apoptosis through an increase in the generation of reactive oxygen species. Thus, we evaluated the antiproliferative effect and a likely mechanism of action of vitamin K3 against cervical epithelial cells transformed by HPV 16 (SiHa cells) assessing the production of total ROS, the mitochondrial membrane potential, the cell morphology, the cell volume, and the cell membrane integrity.

Results Our results show that vitamin $\mathrm{K} 3$ induces an increase in ROS production in SiHa cells, triggering biochemical and morphological events, such as depolarization of mitochondrial membrane potential and decreasing cell volume.

Conclusion Our data showed that vitamin K3 generates an oxidative imbalance in SiHa cells, leading to mechanisms that induce cell death by apoptosis.

Keywords Human Papillomavirus · Vitamin K3 . Apoptosis SiHa cells

$\begin{array}{ll}\text { Abbreviations } \\ \text { ANOVA } & \text { One-way analysis of variance } \\ \text { CCCP } & \text { Carbonyl cyanide 3- clorophenylhydrazone } \\ \text { DHR } & \begin{array}{l}\text { Dihydrorhodamine 123 } \\ \text { Differential interference contrast } \\ \text { microscopy }\end{array} \\ \text { DIC } & \begin{array}{l}\text { Dulbecco's modified Eagle's medium } \\ \text { DMEM }\end{array} \\ \text { DMSO } & \text { Dimethylsulfoxide } \\ \text { EDTA } & \text { Ethylenediaminetetraacetic acid } \\ \text { FACS } & \text { Calibur flow cytometer } \\ \text { FSC-H } & \text { Forward light scatter } \\ \text { H2DCF-DA } & 2^{\prime}, 7^{\prime} \text {-dichlorodihydrofluorescein diacetate } \\ \text { HPV 16 } & \text { SiHa cells } \\ \text { HPV } & \text { Human papillomavirus }\end{array}$




\begin{tabular}{|c|c|}
\hline IC50 & $50 \%$ inhibitory concentration \\
\hline IC90 & $90 \%$ inhibitory concentration \\
\hline IV & Index of variation \\
\hline MTT & $\begin{array}{l}\text { 3-(4,5-dimethylthiazol-2-yl)-2,5- } \\
\text { diphenyltetrazolium bromide }\end{array}$ \\
\hline OD & Optical density \\
\hline PI & Propidium idodite \\
\hline PSN & $\begin{array}{l}\text { Penicillin-streptomycin-neomycin } \\
\text { antibiotic }\end{array}$ \\
\hline RFU & Relative fluorescence units \\
\hline Rh123 & Rhodamine 123 \\
\hline ROS & Reactive oxygen species \\
\hline VERO & Cercopithecus aethiops \\
\hline$\Delta \Psi \mathrm{m}$ & Mitochondrial membrane potential assay \\
\hline
\end{tabular}

\section{Introduction}

Cervical cancer is characterized as a major public health problem. According to the latest global estimates for the year 2012, cervical cancer is the fourth most common cancer among women, with 527,000 new cases [1]. The human papillomavirus (HPV) high carcinogenic risk genotypes 16 and 18 are the most prevalent in about $70 \%$ of all cases of cervical cancer [2,3].

The progression of HPV-associated cervical cancer involves the integration of the HPV genome into the DNA of the cervical cells, leading to the expression of two viral proteins, E6 and E7 [4]. These two proteins play a central role in the growth, proliferation, and apoptosis suppression, leading to the tumor development. Thus, inhibition of these proteins might be an alternative therapeutic mean for the treatment of HPV-cervical cancer [5]. It is known that E6 and E7 proteins are rapidly degraded by the ubiquitinproteasome system $[6,7]$, which activity are enhanced in oxidative stress condition.

Numerous studies have been conducted, demonstrating the broad spectrum of action of vitamin K3 also known as menadione (2-methyl-1,4-naphthoquinone). These studies showed the anticancer effect of vitamin K3 for different types of cancer cells, such as neuroblastoma cell line [8], breast cancer [9], leukemia [10], and lung cancer [11]. This effect of vitamin $\mathrm{K} 3$ has been investigated in vivo and in vitro, and the results suggest that vitamin K3 may induce apoptosis via redox-cycling of the quinone structure to produce reactive oxygen species (ROS) [12, 13].

Therefore, the degradation of HPV proteins E6/E7 and the effect of vitamin $\mathrm{K} 3$ on cancer cell death seem to depend on a unique mechanism that involves the increase in reactive oxygen species (ROS) production. Based on that, our aim was to evaluate the antiproliferative effect and the mechanism of action of vitamin $\mathrm{K} 3$ against cervical epithelial cells transformed by HPV 16 ( $\mathrm{SiHa}$ cells). Our data showed that vitamin K3 induces cellular redox impairment in $\mathrm{SiHa}$ cells, triggering signaling events that induce cell death by apoptosis.

\section{Materials and methods}

\section{Chemicals}

Dulbecco's modified Eagle's medium (DMEM), fetal bovine serum (FBS), penicillin-streptomycin-neomycin (PSN) antibiotic, trypsin, dihydrorhodamine 123(DHR), actinomycin D, ethylenediaminetetraacetic acid (EDTA), 3-(4,5-dimethylthiazol-2-yl)-2,5-diphenyltetrazolium bromide (MTT), 2', $7^{\prime}$-dichlorodihydrofluorescein diacetate (H2DCF-DA), and all other chemicals used were purchased from Sigma Chemical Co. (St. Louis, MO, USA). Propidium iodide (PI) was obtained from Invitrogen (Eugene, OR, USA). All of the other reagents were of analytical grade.

\section{Vitamin K3}

The vitamin K3 was acquired through Sigma-Aldrich (St. Louis, MO, USA) and kept at room temperature. Vitamin $\mathrm{K} 3$ solutions were prepared in DMSO and diluted in culture medium, so that the DMSO concentration did not exceed $1 \%$ in the experiments. For each assay, a new drug dilution was performed. The concentrations of vitamin K3 used in the assays were based on the IC50 (50 \% inhibitory concentration) and IC90 (90\% inhibitory concentration) values.

\section{Cell culture}

Cervical neoplasic epithelial cells (SiHa cell, HPV-16 positive) donated by Dr. Luísa Lina Villa, ICESP-USP, São Paulo, Brazil, and African green monkey kidney Cercopithecus aethiops ATCC CCL-81(VERO) were grown in DMEM medium supplemented with $5000 \mu \mathrm{g}$ streptomycin and $125 \mu \mathrm{g}$ amphotericin $\mathrm{B}$ and $10 \% \mathrm{FBS}$ at $37^{\circ} \mathrm{C}$ in $\mathrm{CO}_{2}$ incubator. After confluence and the cell monolayer formation, cells were trypsinized for $1 \mathrm{~min}$, resuspended in DMEM containing $10 \%$ FCS, and transferred to new plastic bottles.

\section{Cell viability assay}

Cell viability was evaluated in $\mathrm{SiHa}$ cells $\left(5.0 \times 10^{5}\right.$ cells/ $\mathrm{ml})$ and VERO cells $\left(2.5 \times 10^{5}\right.$ cells $\left./ \mathrm{ml}\right)$, and incubated in DMEM supplemented with $10 \%$ fetal bovine serum and 
antibiotics (penicillin, streptomycin, and amphotericin B) at $37{ }^{\circ} \mathrm{C}$ in a $5 \% \mathrm{CO}_{2}$ air mixture. The monolayer obtained after $24 \mathrm{~h}$ was treated with different concentrations ranging from 0.5 to $16 \mu \mathrm{M}$ vitamin $\mathrm{K} 3$ for $48 \mathrm{~h}$ for SiHa cells and $72 \mathrm{~h}$ for VERO cells at $37{ }^{\circ} \mathrm{C}$ with $5 \% \mathrm{CO}_{2}$. The cell viability was evaluated using the method 3-(4,5-dimethyl2-thiazolyl)-2,5-diphenyl-2H-tetrazolium bromide (MTT), used to assess the ability of living cells to reduce MTT in insoluble formazan crystal violet. Intracellular formazan crystals were solubilized with DMSO, and the absorbance of the solution was measured at $570 \mathrm{~nm}$ in a spectrophotometer (Bio Tek-Power Wave XS). The percentage of viability was calculated as optical density (OD) of the cultures with treatment/DO control sample $\times 100 \%$.

\section{Treatment types}

On the basis of MTT results, two different doses IC50: 10.85 $\mu \mathrm{M}$ and IC90: $21.70 \mu \mathrm{M}$ of vitamin K3 were selected for further experiments. Control groups received only media without any vitamin K3 treatment. Vitamin K3treated cells were incubated for $48 \mathrm{~h}$ throughout all the experiments.

\section{Detection of total reactive oxygen species}

ROS production was evaluated during exposure of cells $\mathrm{SiHa}\left(5.0 \times 10^{5}\right.$ cells $\left./ \mathrm{ml}\right)$ to 10.85 and $21.70 \mu \mathrm{M}$ vitamin K3 using $2^{\prime}, 7^{\prime}$-dichloro dihydro fluorescein diacetate (H2DCF-DA) as a detector of intracellular ROS. H2DCFDA can be converted by intracellular esterase into H2DCF, which is oxidized by ROS to highly fluorescent DCF. The cells were washed in Hankes' Balanced Salt Solution (HBSS) and incubated with $10.0 \mathrm{mM}$ DCFH-DA in HBSS in $5 \% \mathrm{CO} 2$ at $37^{\circ} \mathrm{C}$ for $30 \mathrm{~min}$. Then, the cells were washed and incubated with HBSS buffer with iron free or iron supplemented medium. Afterward, the SiHa cells were treated with vitamin $\mathrm{K} 3$ for $48 \mathrm{~h}$ at $37{ }^{\circ} \mathrm{C}$, and washed with HBSS and read. The fluorescence intensity was measured with a Varian fluorescence spectrophotometer with an excitation wavelength of $500 \mathrm{~nm}$ and emission detection at $529 \mathrm{~nm}$. The arbitrary units, relative fluorescence units (RFU), were based directly on fluorescence intensity.

\section{Mitochondrial membrane potential assay}

Mitochondrial membrane potential was evaluated in $\mathrm{SiHa}$ cells $\left(5.0 \times 10^{5}\right.$ cells $\left./ \mathrm{ml}\right)$ treated with 10.85 and $21.70 \mu \mathrm{M}$ vitamin $\mathrm{K} 3$ for $48 \mathrm{~h}$ at $37{ }^{\circ} \mathrm{C}$ in $\mathrm{CO}_{2}$ incubator, using the fluorescent probe Rh123, which accumulates within mitochondria. Afterward, the cells were trypsinized, washed, and incubated with $5 \mathrm{mg} / \mathrm{ml} \mathrm{Rh123}$ for $15 \mathrm{~min}$. CCCP (100.0 mM) was used as a positive control. The data acquisition and analysis were performed using an FACS Calibur flow cytometer (Becton-Dickinson, Rutherford, NJ, USA) equipped with Cell Quest software (Joseph Trotter, The Scripps Research Institute, La Jolla, CA, USA). A total of 10,000 events were acquired in the region that was previously established as the one that corresponded to the cells. Alterations in Rh123 fluorescence were quantified using an index of variation (IV) obtained from the equation (MT-MC)/MC, in which $\mathrm{MT}$ is the median fluorescence for the treated and $\mathrm{MC}$ is the median fluorescence for the control. Negative IV values correspond to the depolarization of the mitochondrial membrane.

\section{Microscopy analysis}

Morphology was evaluated in SiHa cells $\left(5.0 \times 10^{5}\right.$ cells/ ml) seeded in six-well plates with 10.85 and $21.70 \mu \mathrm{M}$ vitamin $\mathrm{K} 3$ after $48 \mathrm{~h}$. The cells were observed under a differential interference contrast (DIC) microscopy (Axiscope plus 2, Zeiss, Germany) and compared with the control group.

\section{Cell volume determination}

Cell volume was evaluated in SiHa cells $\left(5.0 \times 10^{5}\right.$ cells/ ml) treated with 10.85 and $21.70 \mu \mathrm{M}$ vitamin $\mathrm{K} 3$ for $48 \mathrm{~h}$ at $37{ }^{\circ} \mathrm{C}$ in $\mathrm{CO}_{2}$ incubator. After trypsinization, the cells were collected by centrifugation, washed twice, resuspended in PBS, and analyzed using fluorescence-activated cell sorting and a FACS Calibur flow cytometer. Actinomycin D (20.0 mM) was used as a positive control. A total of 10,000 events were acquired in the region that was previously established as the one that corresponded to the cells. Histograms were generated, and the analysis was performed using Cell Quest software; forward light scatter (FSC-H) represents the cell volume.

\section{Cell membrane integrity assay}

The cell membrane integrity was evaluated in $\mathrm{SiHa}$ cells $\left(5.0 \times 10^{5}\right.$ cells $\left./ \mathrm{ml}\right)$ treated with 10.85 and $21.70 \mu \mathrm{M}$ vitamin $\mathrm{K} 3$ for $48 \mathrm{~h}$ at $37{ }^{\circ} \mathrm{C}$ in $\mathrm{CO}_{2}$ incubator using PI, a probe that binds to DNA into cells ruptured membrane. Thereafter, the cells were washed and incubated with $0.2 \mathrm{mg} / \mathrm{ml} \mathrm{PI}$ for $10 \mathrm{~min}$ to verify cell membrane integrity. Digitonin (40.0 mM) was used as a positive control. Data acquisition and analysis were performed using an FACS Calibur flow cytometer equipped with Cell Quest software. A total of 10,000 events were acquired in the region that was previously established as the one that corresponded to the cells. Alterations in the fluorescence of PI were quantified as the percentage of increase in the fluorescence compared with the control (untreated cells). 


\section{Statistical analysis}

Statistical analysis of results (GraphPad Prism version 4.00 for Windows, GraphPad Software, San Diego, CA, USA) was performed by one-way analysis of variance (ANOVA) followed by the Newman-Keuls multiple comparison test or by two-way ANOVA when the effects of two different factors were studied in the same experiment. The results were obtained from three independent experiments, and the bar represents the mean \pm S.E. ${ }^{*} p$-values of $<0.05$ were considered significant.

\section{Results}

\section{Vitamin $\mathrm{K3}$ induces antiproliferative effects in SiHa cells}

The literature provides some evidences of the cytotoxic effect of vitamin K3 on cancer cells [8-11]. Thus, we first evaluated the $\mathrm{SiHa}$ cells viability after $48 \mathrm{~h}$ of treatment to

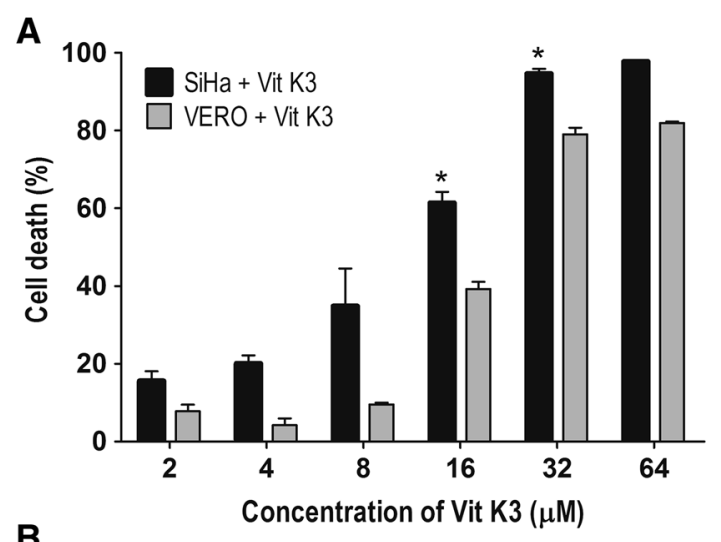

B

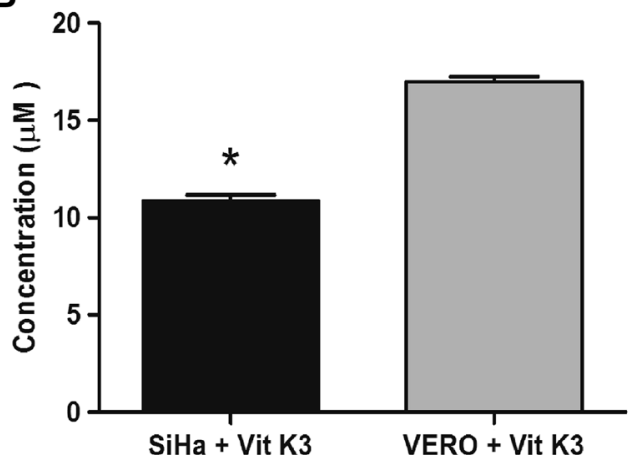

Fig. 1 Analysis of cytotoxic effect of vitamin K3. Cells were cultured in the presence of various concentrations of vitamin K3 $(2-64 \mu \mathrm{M} / \mathrm{mL})$ for $48 \mathrm{~h}$, and cell proliferation was measured by MTT assay. a SiHa $\left(5.0 \times 10^{5}\right.$ cells $\left./ \mathrm{ml}\right)$ and VERO $\left(2.5 \times 10^{5}\right.$ cells $\left./ \mathrm{ml}\right)$ cells viability in vitamin K3-treated cells. b IC50 and CC50 values of vitamin $\mathrm{K} 3$ on $\mathrm{SiHa}$ and VERO cells, respectively. $* p \leq 0.05$ indicates significant difference relative to the vitamin K3-treated VERO cells determine the IC50 and IC90 of vitamin K3 using MTT assay, a standard method to assess cell viability. Figure 1 shows that vitamin $\mathrm{K} 3$ inhibit $\mathrm{SiHa}$ cells proliferation in all tested concentration with an IC50 of $10.85 \mu \mathrm{M}$ and an IC90 of $21.70 \mu \mathrm{M}$. For VERO cells, the cytotoxicity of vitamin $\mathrm{K} 3$ was lower in all tested concentrations with a CC50 (50\% cytotoxic concentration) of $18.4 \mu \mathrm{M}$.

\section{Vitamin $\mathrm{K3}$ increases the production of total ROS in $\mathrm{SiHa}$ cells}

Vitamin K3 has been described to induce tumor death by increasing the cellular formation of $\operatorname{ROS}[12,13]$. To understand that, we evaluated the total ROS production in $\mathrm{SiHa}$ cells after $48 \mathrm{~h}$ of vitamin K3 treatment using flow cytometry, in which the non fluorescent H2DCF-DA is oxidized by ROS, producing fluorescent DCF. Figure 2 shows that vitamin $\mathrm{K} 3$ induced a significant increase $50.1 \%$ in intracellular oxidant species formation by $\mathrm{SiHa}$ cells at both, IC50 and IC90 treated cells compared with the control group.

\section{Vitamin K3 induces depolarization of mitochondrial membrane potential $(\Delta \Psi \mathrm{m})$ in $\mathrm{SiHa}$ cells}

Mitochondria are cytoplasmic organelles with a remarkable function of produce ATP through the respiratory chain and regulate cellular metabolism controlling the mitochondrial ROS production, the mitochondria membrane potential, and the apoptosis cell death [14]. Here, we evaluated the $\Delta \Psi \mathrm{m}$ in vitamin $\mathrm{K} 3$-treated $\mathrm{SiHa}$ cells stained with $\mathrm{Rh}$ 123 , in which Rh123 accumulates within normal mitochondria using flow cytometry. Histograms of total Rh123 fluorescence showed a decrease in fluorescence intensity,

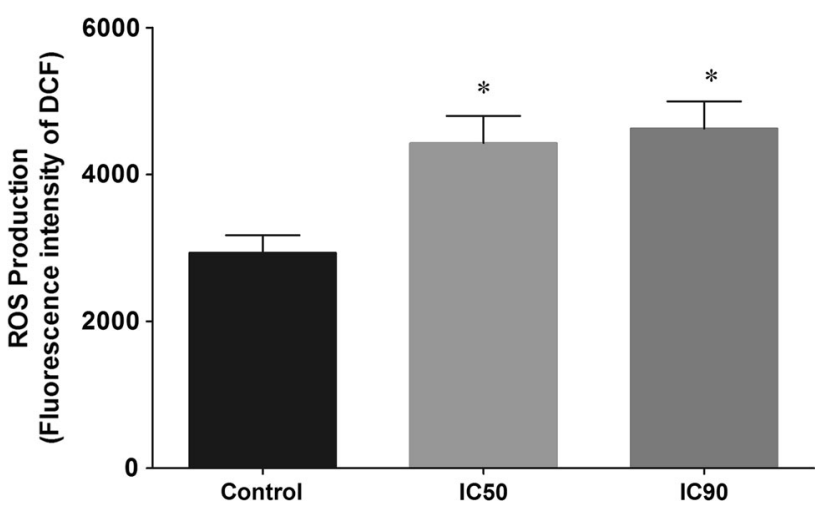

Fig. 2 Total ROS production in vitamin K3-treated SiHa cells for $48 \mathrm{~h}$. Total ROS production was measured in cells stained with $\mathrm{H}_{2}$ DCF-DA and analyzed by fluorescence intensity of DCF. SiHa cells $\left(5.0 \times 10^{5}\right.$ cells $\left./ \mathrm{ml}\right)$ were treated with IC50: $10.85 \mu \mathrm{M}$ and IC90: $21.70 \mu \mathrm{M}$ vitamin $\mathrm{K} 3$ for $48 \mathrm{~h}$. $* p \leq 0.05$, significant difference relative to the control group (untreated cells) 
Table 1 Mitochondrial membrane potential assay in $\mathrm{SiHa}$ cells treated with vitamin $\mathrm{k} 3$ for $48 \mathrm{~h}$ and stained with Rh123

\begin{tabular}{lcr}
\hline $\mathrm{SiHa}$ & & \\
\hline$\mu \mathrm{M}$ & Median & \multicolumn{1}{c}{$\mathrm{IV}^{\mathrm{a}}$} \\
\hline Control & 1893.41 & 0.00 \\
10.85 & $90.99^{*}$ & -0.95 \\
21.70 & $89.77^{*}$ & -0.97 \\
\hline
\end{tabular}

a $I V\left(\mathrm{M}_{\mathrm{T}}-\mathrm{M}_{\mathrm{C}}\right)$, where $\mathrm{M}_{\mathrm{T}}$ corresponds to the median fluorescence for treated $\mathrm{SiHa}$ cells, and $\mathrm{M}_{\mathrm{C}}$ to that median fluorescence for control $\mathrm{SiHa}$ cells

$* p \leq 0.05$, significant difference relative to the control group (untreated cells)

indicating that the mitochondria were depolarized in $\mathrm{SiHa}$ cells treated with 10.85 and $21.70 \mu \mathrm{M}$ of vitamin $\mathrm{K} 3$ for $48 \mathrm{~h}$. As shown in Table 1 and Fig. 3, the reductions of $\Delta \Psi \mathrm{m}$ were 95.19 and $95.26 \%$ for 10.85 and $21.70 \mu \mathrm{M}$ of vitamin $\mathrm{K} 3$, respectively, compared with the control group. The positive control, CCCP, induced $35.6 \%$ the reductions changes in mitochondrial membrane potential. These data show that vitamin $\mathrm{K} 3$ causes the loss of $\Delta \Psi \mathrm{m}$, which is essential for mitochondria ATP production.

\section{Vitamin K3 induces morphological changes in SiHa cells related to apoptosis}

Mitochondrial function is also important to maintain the cell homeostasis, such as the regulation of the cell volume, and cellular morphology [15]. As our data showed that vitamin $\mathrm{K} 3$ causes the loss of $\Delta \Psi \mathrm{m}$, we then evaluated the effect of vitamin $\mathrm{K} 3$ on SiHa cell morphology, using phase microscope of interference contrast difference (DIC). As expected, vitamin $\mathrm{K} 3$ in both tested concentrations caused morphological changes in $\mathrm{SiHa}$ cells closely related to apoptotic-like cell death, reflected here by round-shaped, plasma membrane blebs, and shrink cells (arrow) (Fig. 4c), compared with the control group (Fig. 4a).

\section{Vitamin K3 decreases SiHa cells volume}

The morphological changes induced by vitamin $\mathrm{K} 3$ in $\mathrm{SiHa}$ cells evidenced cell morphology alterations characteristic of apoptosis. Thus, to confirm it, we next evaluated the effect of vitamin $\mathrm{K} 3$ on $\mathrm{SiHa}$ cells volume using flow cytometry. As expected, our results shown that vitamin K3 induced a decrease in cell volume on SiHa cells in both concentrations tested after $48 \mathrm{~h}$. These reductions were 52 and $43 \%$ for IC50 and IC90 (Fig. 5a, b), respectively, compared with the control group. The positive control, actinomycin D, is also shown with a decreased SiHa cell volume of $36 \%$ (Fig. 5c).

\section{Vitamin K3 does not alter SiHa cells membrane integrity}

The previous data prompt us to evaluate the effect of vitamin $\mathrm{K} 3$ on SiHa cells membrane integrity using PI, a probe that is excluded from healthy cells but binds to DNA in ruptured membrane cells. Figure 6 shows that vitamin $\mathrm{K} 3$ does not affect the membrane integrity of $\mathrm{SiHa}$ cells, even at IC 90 dose, compared with the control group. According to the histograms, both concentrations (IC50 and IC90) display the same PI fluorescence intensity compared with the control group (Fig. 6a, b), indicating no alterations of cell membrane integrity. Bright fluorescence was observed with the positive control, digitonin (data not shown). Membrane integrity is also a hallmark of apoptosis [16].

\section{Discussion}

Cervical cancer is one of the most common types of cancer with a high mortality rate among women, being characterized as a major public health problem [17]. Treatment for this type of pathology is typically invasive. Thus, new assets and combinations of drugs are constantly studied [9]. Platinum-based chemotherapy in combination with radiotherapy or surgery is now mainly used, but the efficacy is limited, especially in advanced-stage disease [18, 19]. Nowadays, the search for antitumor drugs of high efficacy and low toxicity for the treatment of cervical cancer is challenging. The effect of vitamin $\mathrm{K} 3$ has been investigated in various types of cancer cells, such as neuroblastoma cell line [8], breast cancer [9], leukemia [10], and lung cancer [11]. Several studies suggest that this vitamin may induce apoptosis through different biochemical pathways, and thereby, signaling mechanism of cell death induced by treatment with vitamin $\mathrm{K} 3$ has been detailed [9, $10,12]$. However, the role of vitamin K3 in cervical cancer and the precise mechanism of action had not been yet elucidated. Therefore, we studied the effect of vitamin K3 on human cervical cancer SiHa cells (HPV 16), and herein, we described some of the biochemical action of vitamin K3 on HPV 16. For this, we investigated the production of total reactive oxygen species; mitochondrial membrane potential; cell morphology; cell volume; and cell membrane integrity.

It is known that biological behavior of malignant tumor cells includes disorderly proliferation and distant metastasis [20]. Vitamin K3 induced cytotoxic effects in SiHa cells, inhibiting cell proliferation. These results were expected, because other authors have also been published similar cytotoxic activity of vitamin K3 against different types of cancer cells [8-10]. To better understanding of the 


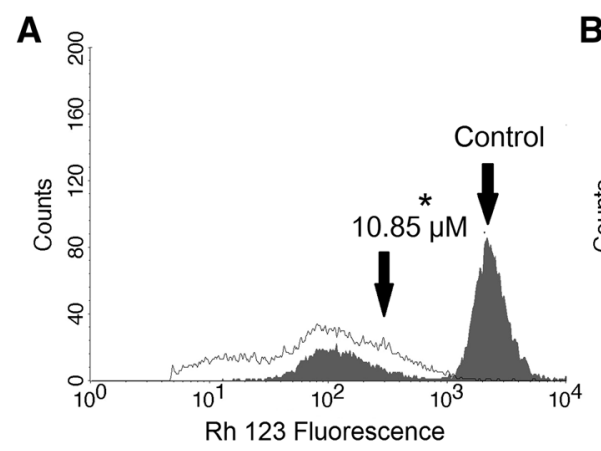

Fig. 3 Mitochondrial membrane potential assay in SiHa cells treated with vitamin $\mathrm{K} 3$ for $48 \mathrm{~h}$ and stained with Rh123, which accumulates within mitochondria and was analyzed by flow cytometry. a SiHa cells $\left(5.0 \times 10^{5}\right.$ cells $\left./ \mathrm{ml}\right)$ treated with IC50: $10.85 \mu \mathrm{M}$. b SiHa cells
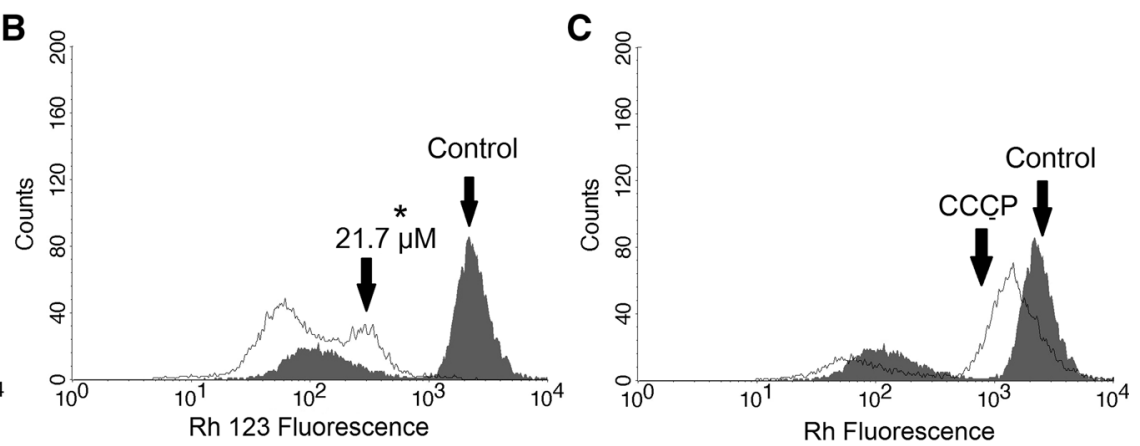

$\left(5.0 \times 10^{5}\right.$ cells $\left./ \mathrm{ml}\right)$ treated with IC90: $21.70 \mu \mathrm{M}$. c SiHa cells treated with $100 \mathrm{mM} \mathrm{CCCP}$ for $48 \mathrm{~h}$. Arrows correspond to tested concentration. $* p \leq 0.05$ indicates significant difference relative to the control group (untreated cells)
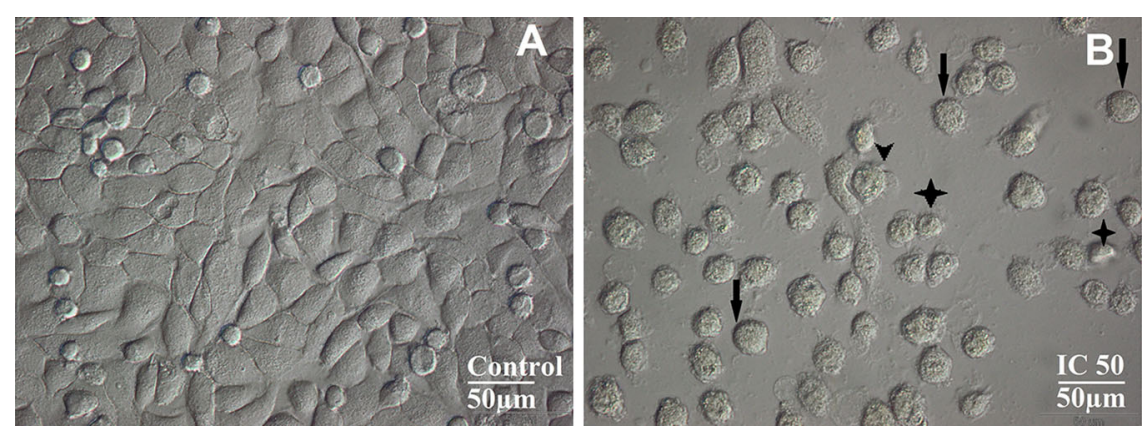

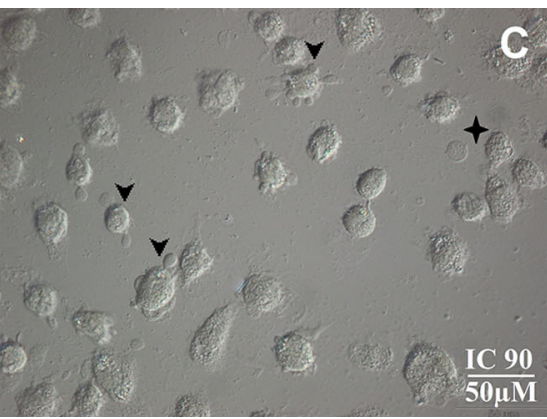

Fig. 4 Morphological changes of vitamin K3-treated SiHa cells $\left(5.0 \times 10^{5}\right.$ cells $\left./ \mathrm{ml}\right)$ after $48 \mathrm{~h}$ using microscope of interference contrast difference $(\times 400)$. a Untreated $\mathrm{SiHa}$ cells. b SiHa cells treated with IC50: $10.85 \mu \mathrm{M}$. c SiHa cells treated with IC90: $21.70 \mu \mathrm{M}$. (arrow) round-shaped; $(\mathbf{\nabla})$ plasma membrane blebs; and (plus) shrink cells. Scale bar $50 \mu \mathrm{M}$

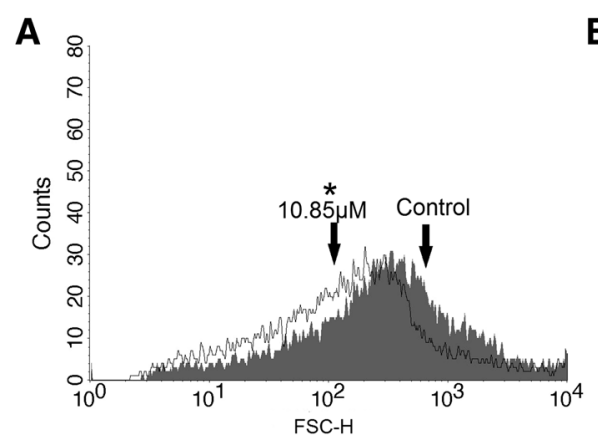

Fig. 5 Cell volume in vitamin K3-treated $\mathrm{SiHa}$ cells $\left(5.0 \times 10^{5}\right.$ cells/ml) after $48 \mathrm{~h}$ using flow cytometry. a SiHa cells treated with IC50: $10.85 \mu \mathrm{M}$. b SiHa cells treated with IC90: $21.70 \mu \mathrm{M}$. c SiHa cells treated with actnomicyn D $20.0 \mathrm{mM}$. FSC-Height was

likely mechanism of cytotoxic effect of vitamin $\mathrm{K} 3$ in $\mathrm{SiHa}$ cells, we performed some biochemical redox analysis of vitamin K3-treated SiHa cells.

Vitamin K3 was able to modify the cellular redox equilibrium, increasing ROS production in $\mathrm{SiHa}$ cells. Differently of healthy cells, tumor cells can easily endure the high levels of ROS, avoiding death and continuously inducing the growth through changes in the metabolism, such as expression of detoxification proteins [21]. We believe that vitamin $\mathrm{K} 3$ is modulating the production of ROS in a way that the cellular ROS concentration overcomes the capacity of tumor to keep the redox state within a limit that promotes cell proliferation. In addition, there are evidences that high ROS level mediated the 

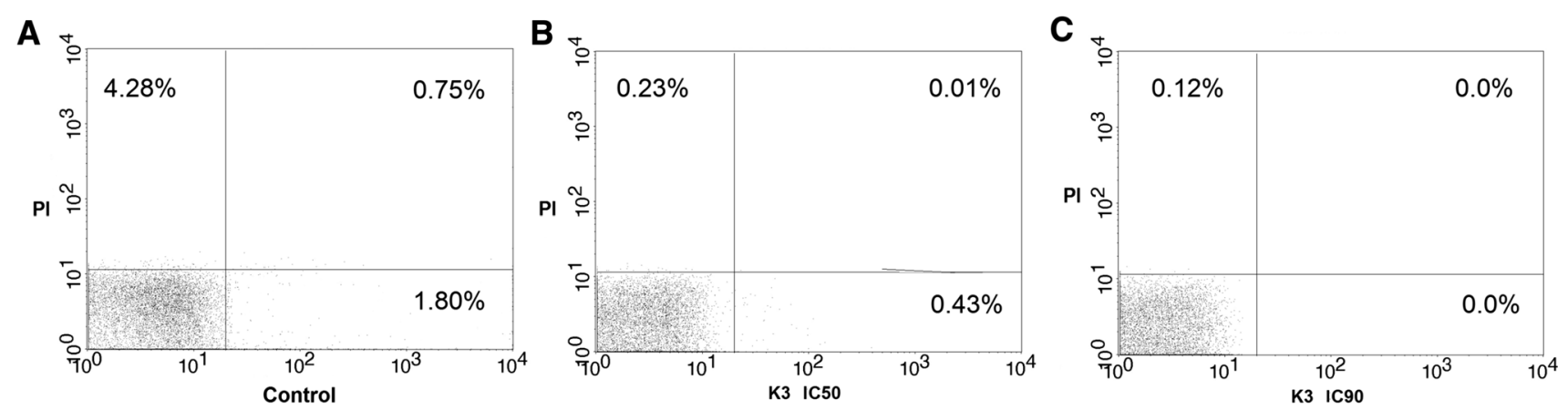

Fig. 6 Cell membrane integrity assay in vitamin K3-treated $\mathrm{SiHa}$ cells $\left(5.0 \times 10^{5}\right.$ cells $\left./ \mathrm{ml}\right)$ after $48 \mathrm{~h}$ in cells stained with PI a probe that binds to DNA in ruptured membrane cells using flow cytometry.

ubiquitin proteasome system activation, leading to E6/E7 degradation, culminating with HPV-immortalized cells death $[6,7]$.

The literature shows that mitochondria are organelles with cytoplasmic regulatory function of cellular metabolism and in cancer cells that metabolism can be altered. In addition, mitochondria are organelles responsible for the synthesis of adenosine triphosphate, as well as being involved in the formation of ROS/RNS [22]. Vitamin K3 induced mitochondrial membrane depolarization in $\mathrm{SiHa}$ cells. Although the "Warburg effect" [23] states that cancer cells have an injured mitochondria and use the aerobic glycolysis instead oxidative phosphorylation, recent studies have shown that cancer cells present distinct energy metabolism and might depend on oxidative phosphorylation to produce energy [24-26]. For example, in the cervical epithelial cancers ( $\mathrm{SiHa}$ and Hela), the ATP synthesis is mainly mitochondrial $[27,28]$. Thus, many antitumor drugs have been described with the mitochondria as their main worthy target [29], including vitamin K3 [9, 30].

Vitamin K3 also induced morphological changes in $\mathrm{SiHa}$ cells related to apoptosis [31]. Apoptosis is a programmed cell death with orchestrated biochemical events that controls cells proliferation [16]. Increase in apoptosis signaling pathway may induce tumor regression [32].

Our results demonstrate that vitamin K3 might be triggering biochemical cell events that activate the signaling pathways for apoptosis cell death. We believe that the effect of vitamin K3 in SiHa cells is related to the redoxcycling of the quinone structure to produce ROS [12, 13]. The increase in ROS might induce the degradation of E6 and E7 proteins, which play a central role in the progression of HPV-associated cervical cancer inducing growth, proliferation, and apoptosis suppression. Thus, our data support further studies, concerning the effect of vitamin K3 on the expression of E6 and E7 proteins, which might be an alternative therapeutic mean for the treatment of HPVcervical cancer [5]. a Untreated SiHa cells. b, c SiHa cells treated with IC50: $10.85 \mu \mathrm{M}$ and IC90: $21.70 \mu \mathrm{M}$. Percentage of PI-stained positive cells is shown in the upper right and left quadrants

Acknowledgments This study was supported by Conselho Nacional de Desenvolvimento Científico e Tecnológico (CNPq), Coordenação de Aperfeiçoamento de Pessoal de Nível Superior (Capes) e Fundação Araucária.

\section{Compliance with ethical standards}

Ethical standards This study was funded by Conselho Nacional de Desenvolvimento Científico e Tecnológico (CNPq), Coordenação de Aperfeiçoamento de Pessoal de Nível Superior (Capes), Financiadora de Estudos e Projetos, Fundação Araucária. Programa de Pós Graduação em Biociências e Fisiopatologia da Universidade Estadual de Maringá, and Complexo de Centrais de Apoio a Pesquisa-UEM.

Conflict of interest All authors have no conflict of interest.

Human participants This article does not contain any studies with human participants or animals performed by any of the authors.

\section{References}

1. INCA (2012) Incidência de Câncer no Brasil. http://www.inca.gov. br/estimativa/2012/index.asp?ID=2015. Accessed 10 Oct 2015

2. Spangle JM, Munger K (2010) The human papillomavirus type 16 E6 oncoprotein activates mTORC1 signaling and increases protein synthesis. J Virol 84(18):9398-9407. doi:10.1128/JVI. 00974-10 (Epub 2010Jul 14)

3. Khan S, Jaffer NN, Khan MN, Rai MA, Shafiq M, Ali A, Pervez S, Khan N, Aziz A, Ali SH (2007) Human papillomavirus subtype 16 is common in Pakistani women with cervical carcinoma. Int J Infect Dis 11:313-317

4. Khan AM, Singer A (2008) Biomarkers in cervical precancer management: the new frontiers. Future Oncol 4:515-524. doi:10. 2217/14796694.4.4.515

5. Jing K, Shin S, Jeong S, Kim S, Song KS, Park JH, Heo JY, Seo KS, Park SK, Kweon GR, Wu T, Park JI, Lim K (2014) Docosahexaenoic acid induces the degradation of HPV E6/E7 oncoproteins by activating the ubiquitin-proteasome system. Cell Death Dis 5:e1524. doi:10.1038/cddis.2014.477

6. Reinstein E, Scheffner M, Oren M, Ciechanover A, Schwartz A (2000) A Degradation of the E7 human papillomavirus oncoprotein by the ubiquitin-proteasome system: targeting via ubiquitination of the N-terminal residue. Oncogene 19:5944-5950

7. Stewart D, Kazemi S, Li S, Massimi P, Banks L, Koromilas AE, Matlashewski G (2004) Ubiquitination and proteasome 
degradation of the E6 proteins of human papillomavirus types 11 and 18. J Gen Virol 85:1419-1426

8. Kitano T, Yoda H, Tabata K, Miura M, Toriyama M, Motohashi S, Suzuki T (2012) Vitamin K3 analogs induce selective tumor cytotoxicity in neuroblastoma. Biol Pharm Bull 35:617-623

9. Yang CR, Liao WS, Wu YH, Murugan K, Chen C, Chao JI (2013) CR108, a novel vitamin K3 derivative induces apoptosis and breast tumor inhibition by reactive oxygen species and mitochondrial dysfunction. Toxicol Appl Pharmacol 273:611-622. doi:10.1016/j.taap.2013.10.007 (Epub 2013 Oct 12)

10. Matzno S, Yamaguchi Y, Akiyoshi T, Nakabayashi T, Matsuyama K (2008) An attempt to evaluate the effect of vitamin K3 using as an enhancer of anticancer agents. Biol Pharm Bull 31:1270-1273

11. Monteiro JP, Martins AF, Nunes C, Morais CM, Lucio M, Reis S, Pinheiro TJ, Geraldes CF, Oliveira PJ (1828) Jurado AS (2013) A biophysical approach to menadione membrane interactions: relevance for menadione-induced mitochondria dysfunction and related deleterious/therapeutic effects. Biochim Biophys Acta 8:1899-1908. doi:10.1016/j.bbamem.2013.04.006 (Epub 2013 Apr 13)

12. Bonilla-Porras AR, Jimenez-Del-Rio M, Velez-Pardo C (2011) Vitamin $\mathrm{K} 3$ and vitamin $\mathrm{C}$ alone or in combination induced apoptosis in leukemia cells by a similar oxidative stress signalling mechanism. Cancer cell international 10(11):19. doi:10.1186/ 1475-2867-11-19

13. Kroemer G, Galluzzi L, Vandenabeele P, Abrams J, Alnemri ES, Baehrecke EH, Blagosklonny MV, El-Deiry WS, Golstein P, Green DR, Hengartner M, Knight RA, Kumar S, Lipton SA, Malorni W, Nunez G, Peter ME, Tschopp J, Yuan J, Piacentini M, Zhivotovsky B, Melino G (2009) Classification of cell death: recommendations of the Nomenclature Committee on Cell Death 2009. Cell Death Differ 16(1):3-11. doi:10.1038/cdd.2008.150 (Epub 2008 Oct 10)

14. Held NM, Houtkooper RH (2015) Mitochondrial quality control pathways as determinants of metabolic health. Bioessays 37(8):867-876. doi:10.1002/bies.201500013 (Epub 2015 May 26)

15. Barbour JA, Turner N (2014) Mitochondrial stress signaling promotes cellular adaptations. Int J Cell Biol 2014:156020. doi:10.1155/2014/156020 (Epub 2014 Jan 22)

16. Franco R, Cidlowski JA (2009) Apoptosis and glutathione: beyond an antioxidant. Cell Death Differ 16:1303-1314. doi:10. 1038/cdd.2009.107 (Epub 2009 Aug 7)

17. Chaturvedi AK, Engels EA, Gilbert ES, Chen BE, Storm H, Lynch CF, Hall P, Langmark F, Pukkala E, Kaijser M, Andersson M, Fossa SD, Joensuu H, Boice JD, Kleinerman RA, Travis LB (2007) Second cancers among 104,760 survivors of cervical cancer: evaluation of long-term risk. J Natl Cancer Inst 99:1634-1643. doi:10.1093/jnci/djn087

18. Yee GP, de Souza P, Khachigian LM (2013) Current and potential treatments for cervical cancer. Curr Cancer Drug Targets 13:205-220
19. Chao A, Lin CT, Lai CH (2014) Updates in systemic treatment for metastatic cervical cancer. Curr Treat Options Oncol 15:1-13. doi:10.1007/s11864-013-0273-1

20. Ye J, Yin L, Xie P, Wu J, Huang J, Zhou G, Xu H, Lu E, He X (2015) Antiproliferative effects and molecular mechanisms of troglitazone in human cervical cancer in vitro. Onco Targets Ther 8:1211-1218. doi:10.2147/OTT.S79899 (eCollection 2015)

21. Perera RM, Bardeesy N (2011) Cancer: when antioxidants are bad. Nature 475(7354):43-44. doi:10.1038/475043a

22. Murphy MP (2009) How mitochondria produce reactive oxygen species. Biochem J 417(1):1-13. doi:10.1042/BJ20081386

23. Koppenol WH, Bounds PL, Dang CV (2011) Otto Warburg's contributions to current concepts of cancer metabolism. Nat Rev Cancer 11(5):325-337. doi:10.1038/nrc3038 (Epub 2011 Apr 14)

24. Hsu PP, Sabatini DM (2008) Cancer cell metabolism: warburg and beyond. Cell 134:703-707

25. Lim HY, Ho QS, Low J, Choolani M, Wong KP (2011) Respiratory competent mitochondria in human ovarian and peritoneal cancer. Mitochondrion 11(3):437-443. doi:10.1016/j.mito.2010. 12.015 (Epub 2011 Jan 3)

26. Scott DA, Richardson AD, Filipp FV, Knutzen CA, Chiang GG, Ronai ZA, Osterman AL, Smith JW (2011) Comparative metabolic flux profiling of melanoma cell lines: beyond the Warburg effect. J Biol Chem 286(49):42626-42634. doi:10.1074/jbc. M111.282046 (Epub 2011 Oct 13)

27. Busk M, Horsman MR, Kristjansen PE, van der Kogel AJ, Bussink J, Overgaard J (2008) Aerobic glycolysis in cancers: implications for the usability of oxygen-responsive genes and fluorodeoxyglucose-PET as markers of tissue hypoxia. Int J Cancer 122(12):2726-2734. doi:10.1002/ijc.23449

28. Bonuccelli G, Tsirigos A, Whitaker-Menezes D, Pavlides S, Pestell RG, Chiavarina B, Frank PG, Flomenberg N, Howell A, Martinez-Outschoorn UE, Sotgia F, Lisanti MP (2010) Ketones and lactate "fuel" tumor growth and metastasis: Evidence that epithelial cancer cells use oxidative mitochondrial metabolism. Cell Cycle 9(17):3506-3514

29. Ralph SJ, Low P, Dong L, Lawen A, Neuzil J (2006) Mitocans: mitochondrial targeted anti-cancer drugs as improved therapies and related patent documents. Recent Pat Anticancer Drug Discov 1:327-346

30. Akiyoshi T, Matzno S, Sakai M, Okamura N, Matsuyama K (2009) The potential of vitamin K3 as an anticancer agent against breast cancer that acts via the mitochondria-related apoptotic pathway. Cancer Chemother Pharmacol 65:143-150. doi:10. 1007/s00280-009-1016-7 (Epub 2009 May 16)

31. Paul A, Das S, Das J, Samadder A, Bishayee K, Sadhukhan R, Khuda-Bukhsh AR (2013) Diarylheptanoid-myricanone isolated from ethanolic extract of Myrica cerifera shows anticancer effects on HeLa and PC3 cell lines: signalling pathway and drug-DNA interaction. $\mathrm{J}$ Integr Med 11:405-415. doi:10.3736/ jintegrmed2013057

32. Igney FH, Krammer PH (2002) Death and anti-death: tumour resistance to apoptosis. Nat Rev Cancer 2:277-288 